\title{
ОЦЕНКА РИСКОВ ПЕРЕОПЫЛЕНИЯ КУКУРУЗЫ ПРИ СОВМЕСТНОМ ВЫРАЩИВАНИИ НЕСКОЛЬКИХ ЛИНИЙ В УСЛОВИЯХ ЮГО-ВОСТОКА ЕВРОПЕЙСКОЙ ЧАСТИ РОССИИ
}

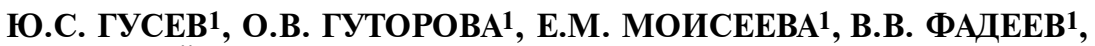 \\ С.А. ЗАЙЦЕВ 2 , Д.П. ВОЛКОВ 2 , Е.А. ЖУК 2 , И.В. ВОЛОХИНА', \\ М.И. ЧУМАКОВ ${ }^{\circledR}$
}

\begin{abstract}
Новый Федеральный закон (ФЗ № 358 от 03.07.2016), действующий в России с 2018 года, разрешает выращивание и тестирование генетически-модифицированных (ГМ) растений в рамках научных исследований, однако научно обоснованная оценка безопасного совместного выращивания нетрансформированных и ГМ-растений, в частности кукурузы, в России пока отсутствует. В настоящей работе в условиях Саратовской области впервые установлено, что расстояние 10-15 м достаточно для предотвращения переопыления линий кукурузы с допустимым присутствием $0,9 \%$ генетического материала донора независимо от линии реципиента, сроков цветения донора и реципиента и направления ветра. Целью работы была оценка влияния расстояний между донором и реципиентом пылыцы, направления ветра, синхронности цветения донора и реципиента и наличия между ними буферной зоны на частоту скрещивания разных линий кукурузы в смешанных посевах. Опытные растения кукурузы (Zea mays L.) линий Коричневый маркер (КМ), ГПЛ1, Зародышевый маркер Саратовский - Пурпурный (ЗМС-П), Пурпурная Саратовская (ПС), а также гибриды Пурпурный (ГП), Радуга и Тестер 3 выращивали в 2018-2019 годах на опытном поле РосНИИСК «Россорго» (Саратовская обл., юго-восток европейской части России). В 2018 году донорами пыльцы были гибрид Пурпурный и линия ЗМС-П. Плотность высадки составляла

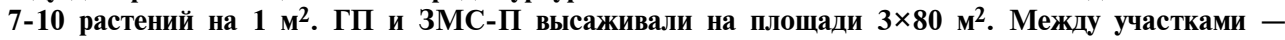
донорами пыльцы была высажена кукуруза линий КМ и ГПЛ-1, образующих буферную зону, а вокруг них располагались участки с реципиентными линиями (гибриды Радуга и Тестер 3), имеющими желтые зерновки, общей площадью $1290 \mathrm{~m}^{2}$. В сентябре отбирали по 5-12 початков каждой реципиентной линии. Частоту переопыления подсчитывали, вычисляя отношение числа пурпурных (результат опыления ГП) или желтых зерен с пурпурным пятном (результат опыления линией ЗМС-П) к общему числу зерен у линий-реципиентов. В эксперименте 2019 года донором пыльцы служила инбредная линия Пурпурная Саратовская. Линию ПС высаживали на участке площадью $3 \times 5$ м² $^{2}$ вокруг которого была создана буферная зона с посевом суданской травы сорта Аллегория шириной 3 м в восточном и западном направлениях и длиной 15 м в юго-западном и северо-восточном направлениях. Вокруг буферной зоны была высажена желтозерная кукуруза гибрида Радуга. Частоту скрещиваний рассчитывали, как отношение числа пурпурных зерен к общему числу зерен на початках гибрида Радуга. По данным 2018 года, уже на расстоянии 10 м от ГП процент скрещиваний не превышал принятый в Европейском Союзе и России порог (0,9\% содержания ГМ-сырья в пищевых продуктах). В полевом эксперименте 2019 года наблюдалось не более $0,9 \%$ пурпурных зерен у реципиента пыльцы Радуга при использовании буферной зоны 15 м и более от донора (линии ПС) в направлении розы ветров. В зависимости от сочетания разных факторов в 2018 году частота скрещиваний от двух доноров пылыцы колебалась в пределах 0,1-13,2 \%. Частота скрещиваний у гибрида Радуга на расстоянии 1-4 м от ГП была в 3 раза выше, чем на расстоянии 10 м. На расстоянии 40 м этот показатель снизился в 11 раз по сравнению с расстоянием 1-4 м и составил 0,1\%. У линии ГПЛ-1 (разница в начале цветения с донором ГП - 9 сут) процент переопылений был в 4 раза меныше, чем у линии КМ (разница в начале цветения с донором ГП - 1 сут). Высокорослый донор ГП препятствовал распространению пыльцы более низкорослой линии ЗМС-П на реципиентов (Тестер 3 и Радуга) в направлении розы ветров. На основании результатов полевых экспериментов изолирующее расстояние 15 м и более может быть рекомендовано для исключения переопления кукурузы в пределах порога 0,9 \% в условиях юговостока европейской части России.
\end{abstract}

Ключевые слова: ГМ-растения, риски переопыления, кукуруза, буферные зоны.

Кукуруза (Zea mays L.) - одно из наиболее значимых сельскохозяйственных растений. С 2010 года урожай кукурузы в мире вырос с 800 до 1122 млн т (1). В Российской Федерации в 2019 году, по данным

\footnotetext{
* Работа выполнена по Программе фундаментальных научных исследований государственных академий наук на 2020 годы (№ гос. регистрации АААА-А17-117102740101-5) (ГМ-кукуруза получение, оценка рисков) и при финансовой поддержке гранта № 18-29-14048мк РФФИ (моделирование поведения ГМ-кукурузы в полевых условиях).
} 
Министерства сельского хозяйства, урожай кукурузы на зерно составил 13,9 млн т, что превысило показатель 1995 года (1,7 млн т) более чем в 8 раз (http://mcx.ru/press-service/news/v-2019-godu-urozhaynost-zernovykh-v-rossiivyrosla-na-4-7/).

Фотосинтез кукурузы относится к типу C4, что предполагает бо́льшую эффективность поглощения углекислого газа в условиях хорошей освещенности и повышенных температур. Кроме того, кукуруза засухоустойчива, и потепление климата вкупе с учащающимися засухами позволит расширять ареал ее культивирования в России. В Европе повышение среднегодовой температуры на $1^{\circ} \mathrm{C}$ уже отодвинуло границу распространения кукурузы на 200 км к северу (2).

Применение современных геномных технологий в растениеводстве одно из приоритетных направлений использования биотехнологии в сельском хозяйстве развитых и развивающихся стран (3). Использование генетически модифицированных (ГМ) растений для выращивания в промышленных масштабах началось с 1996 года. В настоящее время почти треть всей выращиваемой кукурузы составляет ГМ-кукуруза (4), которая дает наибольший урожай ГМ-зерна.

В Российской Федерации вплоть до июня 2018 года действовал полный запрет на выращивание ГМ-культур. Согласно действующему с июня 2018 года Ф3 № 358 (от 03.07.2016), в России впервые разрешено выращивание и тестирование ГМ-растений в рамках научных исследований. Однако параметры безопасного выращивания ГМ-растений при этом не регламентированы и требуют изучения. Каждая страна-участница Конвенции о биологическом разнообразии 1993 года, в том числе Россия, должна разработать стратегию и программу по сохранению и использованию биоресурсов с учетом их безопасного воспроизводства $(5,6)$. Следовательно, необходима оценка критериев безопасного совместного выращивания нетрансформированных и ГМ-сортов растений, в частности кукурузы.

Кукуруза - однодомное ветроопыляемое растение, что служит источником повышенного риска для распространения пыльцы ГМ-сортов, скрещивание с которыми нежелательно в производственных посевах. В мире не сложилось единого подхода к правовому регулированию выращивания ГМ-культур. Существуют две противоположные точки зрения на проблему совместного выращивания ГМ- и неГМ-растений (7). В странах Европейского Союза и Северной и Южной Америки в основу регулирования положены принципиально разные модели по оценке рисков в отношении генетически модифицированных организмов (ГМО). Эти подходы получили название процесс-ориентированного (principle-based) и продукт-ориентированного (product-based) (8). В первом случае признается риск процесса генетической модификации, во втором - риск, связанный с ее результатом и объектом (ГМО или производная продукция) $(9,10)$. В ряде стран (США, Канада, Аргентина, Бразилия, Испания) разрешено культивирование ГМрастений. Другие государства, в частности страны Европейского Союза и Россия, приняли решение о запрете коммерческого выращивания ГМ-культур на своей территории $(11,12)$.

Анализ накопленного за последние 20 лет мирового опыта по экспериментальной оценке рисков переопыления при совместном выращивании ГМ- и неГМ-кукурузы дан в ряде обзоров (13-15). Буферные расстояния в разных странах могут составлять от 25 до 800 м в зависимости от законодательных актов (16-18). Причем буферные расстояния, измеренные в различных регионах мира, имеют очень незначительные различия (19-21).

Расстояние между полями было определено как ключевой фактор 
распространения ГМ-кукурузы в нетрансгенных посевах (22). Как следствие, существующие правила в основном касаются поддержания фиксированного изоляционного расстояния между ГМ-полями и ближайшими неГМ-полями (23). Однако другие факторы, такие как синхронность цветения донора и реципиента пыльцы, ветер, относительные размеры и форма полей, а также пространственное распределение различных типов полей, тоже могут влиять на буферные расстояния $(24,25)$.

В России совместное выращивание ГМ- и неГМ-кукурузы систематически не исследовалось. В 2010 году в условиях Краснодарского края проведена первая экспериментальная оценка распространения ГМ-кукурузы в нетрансгенных посевах культуры (26). Автор утверждает, что культурные сорта кукурузы должны быть посажены на расстоянии не менее 200 м от трансгенных сортов кукурузы, при этом необходимо создать барьеры в направлениях потока пыльцы. Однако в указанной работе не рассматривался вопрос, на каком расстоянии можно выращивать ГМ- и неГМ-кукурузу, чтобы не превышать допустимое $(0,9 \%)$ в России содержание ГМпродукта в общем урожае зерна. Поскольку в России до июня 2018 года действовал полный запрет на выращивание ГМ-растений в открытой среде, для изучения распространения пыльцы ГМ-кукурузы в полевых экспериментах, начатых в мае 2018 года, мы использовали технологию, имитирующую распространение пыльцы ГМ-сортов среди производственных сортов в условиях свободного опыления. Суть технологии сводится к оценке распространения пыльцы донора на основании проявления доминантного признака (пурпурное или белое зерно) в потомстве желтозерных линий растений-реципиентов (27-29).

В 2015 году в России был разработан «Внутриотраслевой стандарт по выращиванию семенных участков кукурузы, проверке и подготовке семян кукурузы гибридов первого поколения» (ВОСТ 01.09.ГК. Координационный совет по развитию семеноводства кукурузы в России, 2015), который мог бы служить ориентиром по безопасным расстояниям выращивания кукурузы. Однако в стандарте отсутствует информация об экспериментальных работах, лежащих в основе этих рекомендаций, и не учитывается возможность присутствия допустимых 0,9 \% ГМО-продуктов, что может значительно влиять на безопасные для совместного выращивания расстояния.

В настоящей работе в условиях Саратовской области (юго-восток европейской части России) впервые установлено, что расстояние 10-15 м достаточно для предотвращения переопыления линий кукурузы с допустимым присутствием $0,9 \%$ генетического материала донора независимо от линии реципиента, сроков цветения донора и реципиента и направления ветра.

Целью работы была оценка влияния расстояний между донором и реципиентом пыльцы, направления ветра, синхронности цветения донора и реципиента и наличия между ними буферной зоны на частоту скрещивания разных линий кукурузы в смешанных посевах.

Методика. Опытные растения кукурузы линий Коричневый маркер (KM), ГПЛ-1, Зародышевый маркер Саратовский - Пурпурный (ЗМС-П), Пурпурная Саратовская (ПС), гибрид Пурпурный (ГП) селекции Саратовского национального исследовательского государственного университета им. Н.Г. Чернышевского, а также гибриды Радуга и Тестер 3 селекции Российского научно-исследовательского и проектно-технологического института сорго и кукурузы (РосНИИСК «Россорго») выращивали в 2018-2019 годах на опытном поле РосНИИСК «Россорго» (п. Зональный, Саратовский р-н, Саратовская обл.).

В 2018 году донорами пыльцы были гибрид Пурпурный (ГП) и линия 
Зародышевый маркер Саратовский - Пурпурный (ЗМС-П). ГП был получен посредством скрещивания линии Пурпурная Саратовская (ПС) и гибрида Радуга и впоследствии самоопылялся в течение нескольких лет (О.В. Гуторова, личное сообщение).

Плотность высадки составляла 7-10 растений на 1 м². ГП и ЗМС-П высаживали на участке $3 \times 80$ м. Между участками - донорами пыльцы была высажена кукуруза линий Коричневый маркер (KM) и ГПЛ-1, образующих буферную зону, а вокруг них располагались участки с реципиентными линиями (гибриды Радуга и Тестер 3), имеющими желтые зерновки, общей площадью 1290 м². В сентябре 2018 года отбирали по 5-12 початков каждой реципиентной линии, фотографировали их в двух проекциях, все зерновки отделяли от початка и анализировали. Частоту переопыления подсчитывали на початках линий-реципиентов, вычисляя отношение числа пурпурных (результат опыления ГП) или желтых зерен с пурпурным пятном (результат опыления линией ЗМС-П) к общему числу зерен у линий-реципиентов.

В эксперименте 2019 года донором пыльцы служила инбредная линия Пурпурная Саратовская, созданная на основе американской линии. Линию ПС высаживали на участке размером $3 \times 5$ м, вокруг которого была создана буферная зона с посевом суданской травы Аллегория Sorghum $\times$ drummondii (Steud.) Millsp. \& Chase, шириной 3 м в восточном и западном направлениях и длиной 15 м в юго-западном и северо-восточном направлениях. Вокруг буферной зоны была высажена желтозерная кукуруза гибрида Радуга. Вычисление расстояний от углов прямоугольного участка донора до углов прямоугольных делянок реципиента (ближняя и дальняя точки) А5, A6, A10, A11 и E5, E6, E10, E11 проводили посредством расчета гипотенуз. Расстояния до ближней и дальней точек от соответствующего угла прямоугольного участка донора пыльцы до делянок реципиента А6, A11, E6, E11 составляло 6 и 12 м, до делянок A5, A12, E5, E12 - 10 и 16 м. Частоту скрещиваний рассчитывали, как отношение числа пурпурных зерен к общему числу зерен на початках гибрида Радуга. В сентябре 2019 года собрали все початки на каждой делянке линии-реципиента, подсчитывали общее число початков на делянке и общее число зерен с початков. Среднее число зерен на початок высчитывали посредством деления общего числа зерен на делянке на число початков.

Общее число собранных и проанализированных зерен в 2018 году составило 17409 шт., в 2019 году - 201284 шт.

Статистическую обработку проводили в программе Microsoft Excel 2010 с использованием пакета статистики. Вычисляли средние арифметические значения $(A M)$ и средние квадратические отклонения $( \pm \mathrm{SD})$. Достоверность различий определяли с помощью $t$-критерия Стьюдента $(\mathrm{p} \leq 0,05)$. В эксперименте 2018 года каждая среднеарифметическая величина была получена на основании 5-12 повторностей. В 2019 году для каждого расстояния использовали по 5 повторностей (делянок), в каждой из которых анализировалось от 3 до 17 початков.

Результаты. Схема расположения экспериментальных посевов кукурузы на опытном поле РосНИИСК «Россорго» в оба года исследований представлена на рисунке 1.

В 2018 году донорами пыльцы были гибрид Пурпурный (ГП) и линия Зародышевый маркер Саратовский - Пурпурный (ЗМС-П). ГП - высокорослый (2,0-2,5 м), имеет доминантную пурпурную (антоциановую) окраску стебля, листьев, зерен. Генетически маркированная линия кукурузы ЗМС-П (30) обладает пурпурной окраской вегетативных частей растения, метелок, зародыша, эндосперма, более низкорослая (1,5 м) по сравнению с 
ГП, средне-позднеспелая. Пурпурную окраску алейронового слоя эндосперма и зародыша обеспечивает ген $R-g$. При скрещивании 3МС-П с желтозерными линиями-реципиентами гибридные зерновки имели окрашенный пурпурным пятном эндосперм. В эксперименте 2019 года донором пыльцы служила инбредная линия Пурпурная Саратовская (ПС), созданная на основе американской линии Пурпурный тестер (31) и скороспелой линии саратовской селекции ГПЛ-1. Среднеспелая высокорослая (1,8 м) линия ПС обладает пурпурной (антоциановой) окраской зерна, листьев и стебля, определяемой доминантными генами $A 1, A 2, B, P l, P r, R-g, C$. В частности, ген $R-g$ контролирует пурпурную окраску алейрона зерна (32).
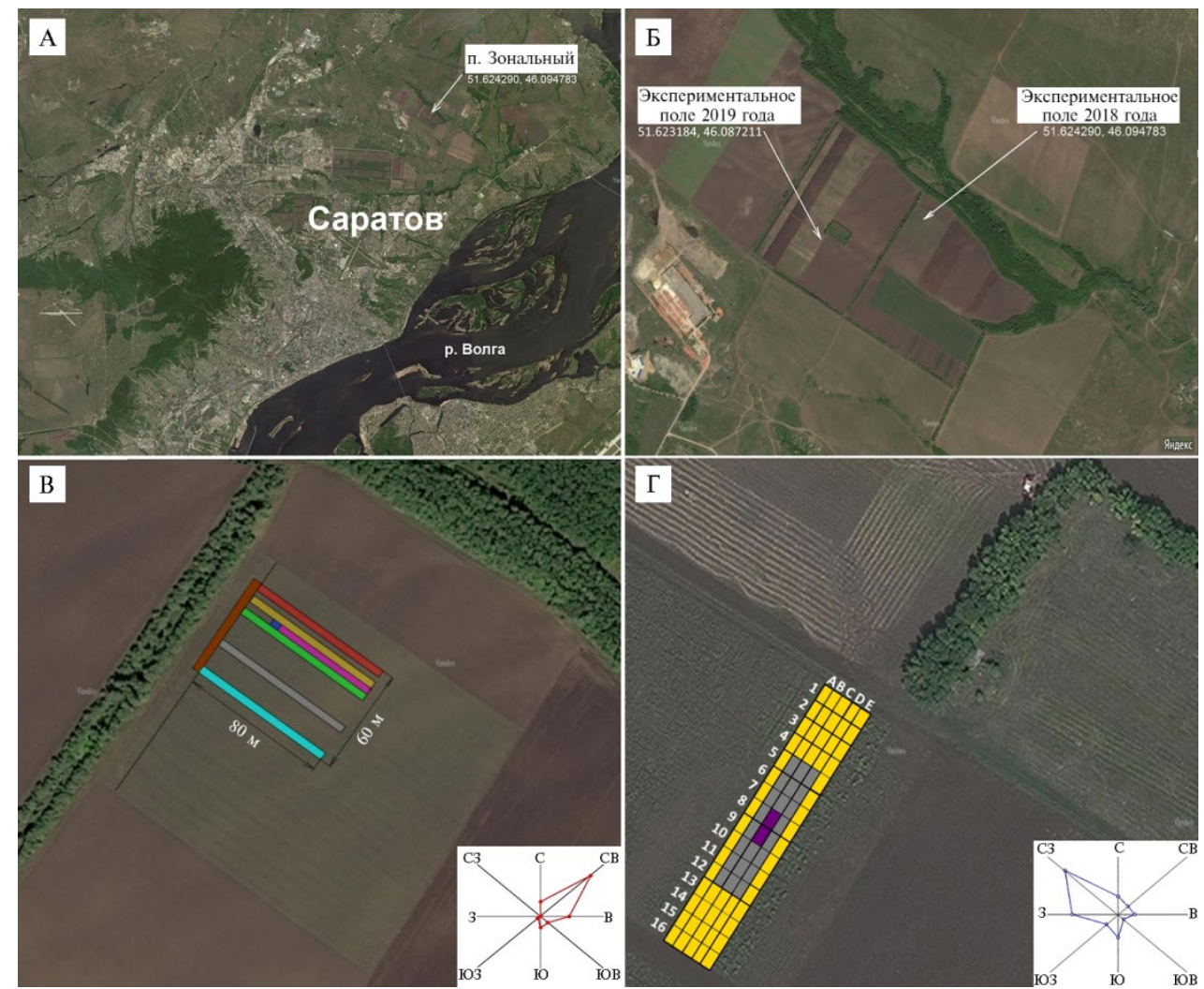

Рис. 1. Местоположение экспериментальных посевов кукурузы (Zea mays L.), на которых велась оценка рисков переопыления при выращивании генно-модифицированных (ГМ) растений (https://yandex.ru/maps/194/saratov). Роза ветров в период цветения приведена согласно http://weatherarchive.ru. Ориентация карты (стороны света) указана на розе ветров.

А - расположение экспериментальных полей в 2018-2019 годах (п. Зональный) относительно г. Саратова и р. Волги.

Б - общий вид экспериментальных полей в 2018-2019 годах.

В - схема посадок кукурузы на экспериментальном поле 2018 года: зеленый цвет гибрид Пурпурный (ГП, донор пыльцы), желтый цвет - линия Зародышевый маркер Саратовский - Пурпурный (донор пыльцы); красный цвет - гибрид Радуга (реципиент пыльцы, 10 м от ГП на восток), бирюзовый цвет - гибрид Радуга (реципиент пыльцы, 40 м от ГП на запад), коричневый цвет - гибрид Радуга (реципиент пыльцы, 1-4 м от ГП на север), серый цвет - гибрид Тестер 3 (реципиент пыльцы, 20 м от ГП запад), синий цвет - линия ГПЛ-1, розовый цвет - линия Коричневый маркер.

Г - схема посадок на экспериментальном поле (2019 год): фиолетовый цвет - линия Пурпурная Саратовская (донор пыльцы, $30 \mathrm{~m}^{2}$ ), серый цвет - буферная зона с посевом суданской травы сорта Аллегория (330 м²), желтый цвет - гибрид Радуга (реципиент пыльцы).

В 2018 году дожди в период цветения кукурузы отсутствовали, а влажность воздуха во время выхода пыльцы из пыльников варьировала от 
$75 \%$ в утренние часы до $36 \%$ днем. Максимальная скорость ветра в период цветения была 5,7 м/с (31 июля), средняя скорость ветра - 3,1 м/с. Направление ветра до 1 августа было преимущественно северо-восточным, со 2 августа - преимущественно северным, северо-западным (см. рис. 1, В). Температура в период цветения кукурузы в утренние часы колебалась в пределах $16-22{ }^{\circ} \mathrm{C}$, в дневные часы $-22-29^{\circ} \mathrm{C}$.

В 2019 году дождь в исследуемый период был только 26 июля. Относительная влажность в период цветения во время выхода пыльцы из пыльников колебалась от 38 до 77 \%. Основное направление ветра - северозападное, но в период с 25 по 27 июля оно было северо-восточным (см. рис. 1, Г). В утренние часы температура колебалась в пределах $14-21{ }^{\circ} \mathrm{C}$, дневная температура составляла $18-30{ }^{\circ} \mathrm{C}$.

Известно, что на распространение пыльцы оказывают влияние температура, влажность воздуха, количество осадков, жизнеспособность, общий объем пыльцы, потоки ветра, профиль ландшафта, конфигурация реципиентного поля, одновременность цветения отцовских и материнских растений $(12,33)$. При этом нет данных о том, как влияют на частоту переопыления высота донора пыльцы и угол расположения листьев реципиента.

Жизнеспособность пыльцы, или способность пыльцы прорастать через пестичные нити в зародышевый мешок, - важное условие для перекрестного опыления. На срок жизнеспособности пыльцы кукурузы (от 1 до 24 ч) влияют влажность и температура $(34,35)$. Как правило, пыльца высыпается из пыльников в сухих жарких условиях, в основном с утра до полудня $(16,36)$. Цветение линий-доноров пыльцы кукурузы в условиях Саратовской области в 2018 году продолжалось с 25 июля по 5 августа. Температура воздуха и влажность в этот период были благоприятными для опыления.

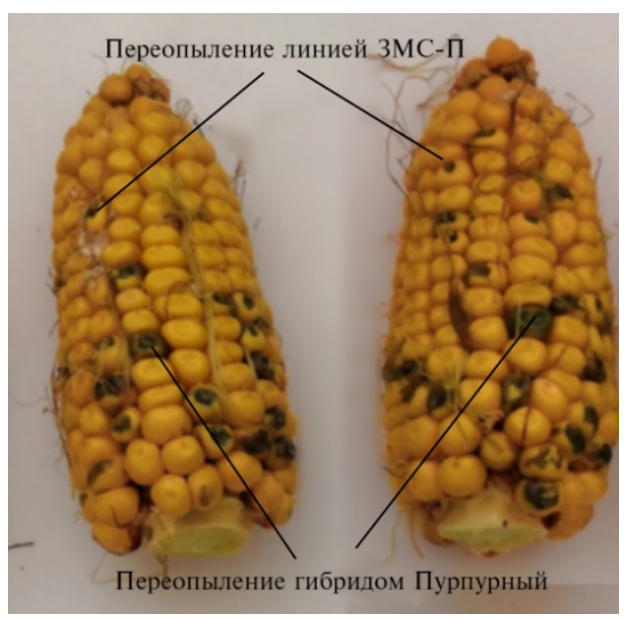

Рис. 2. Внешний вид початков кукурузы (Zea mays L.), полученных в результате свободных скрещиваний между донорами пыльцы (гибрид Пурпурный ГП, линия зародышевый маркер Саратовский - Пурпурный ЗМС-П) и линией-реципиентом ГПЛ-1 (опытное поле РосНИИСК «Россорго», п. Зональный, Саратовский р-н, Саратовская обл., 2018 год). Пурпурное пятно на желтых зернах - результат опыления линией ЗМС-П, полностью окрашенное пурпурное зерно - peзультат опыления ГП.

От скорости ветра в значительной степени зависит расстояние, на которое будет распространяться пыльца после выброса из пыльников. В период экспериментов 2018 года скорость ветра утром и днем составляла 2,4-5,7 м/с и при сохранении жизнеспособности пыльцы в течение 1 ч она могла бы распространяться на 14 км. Однако, поскольку пыльца кукурузы достаточно крупная (средний диаметр 90 мкм) и относительно тяжелая $(0,25$ мкг), скорость ее оседания высока и в реальных условиях поля пыльца разносится относительно недалеко (17, 39). У 90-93 \% всей пыльцы от линии-донора ЗМС-П ее размер составлял 120-140 мкм и мало отличался от размеров пыльцы других линий диплоидной кукурузы саратовской селекции (37), то есть этот признак, вероятно, не влиял на распространение пыльцы.

В жарких и сухих условиях Сaратовской области в 2018 году частота переопыления пыльцой линий-доноров составляла от 0,1 до 13,2 \% для 
разных реципиентных линий (табл. 1). Максимальную частоту переопыления наблюдали для линий КМ и ГПЛ-1, находящихся в непосредственной близости от доноров пыльцы: 13,2 \% для КМ при опылении пыльцой гибрида Пурпурный и 10,5 \% для ГПЛ-1 при опылении пыльцой ЗМС-П. Внешний вид початков кукурузы, полученных в результате переопыления, представлен на рисунке 2.

Частота скрещиваний у гибрида Радуга на расстоянии 10 м была в 3 раза меньше $(0,3 \%)$ ( $\mathrm{p} \leq 0,05)$, чем на расстоянии $1-4$ м при опылении пыльцой ГП $(0,9 \%)(\mathrm{p} \leq 0,05)$, тогда как при опылении пыльцой ЗМС-П на том же расстоянии показатель составил $0,05 \%(\mathrm{p} \leq 0,05)$ и был в 4 раза меньше, чем на расстоянии $1-4$ м $(0,2 \%)(\mathrm{p} \leq 0,05)$. На расстоянии 40 м от ГП частота скрещиваний снизилась в 11 раз и составила $0,08 \%(\mathrm{p} \leq 0,05)$, а растений, опыленных пыльцой линии ЗМС-П, мы не обнаружили. Интересно, что у гибрида Радуга даже на близком расстоянии содержание пурпурных зерен в массе желтых в потомстве практически не превышало принятый в странах Европейского Союза и России порог 0,9\% присутствия ГМ-продуктов в пище (урожае).

В работе, проведенной в условиях Краснодарского края (22), остался невыясненным вопрос, на каком расстоянии можно выращивать ГМ- и неГМ-кукурузу, чтобы не превышать допустимое в России содержание ГМпродукта в общем урожае зерна. Если учесть, что в общем урожае зерна может содержаться 0,9 \% ГМ-продукта, то расстояние в 200 м, указанное автором для предотвращения переопыления кукурузы, значительно сократилось бы.

1. Частота встречаемости пурпурных зерен в потомстве желтозерных реципиентных линий кукурузы (Zea mays L.) при свободном опылении ( $A M \pm \mathrm{SD}$, опытное поле РосНИИСК «Россорго», п. Зональный, Саратовский р-н, Саратовская обл., 2018 год)

\begin{tabular}{l|c|c|c|cc|c}
\hline Реципиент пыльцы & А & Б & В & $\Gamma$ & Д & E \\
\hline КМ & $1-4$ м, восток & $24.07-06.08$ & $332 \pm 93,0$ & $44,3 \pm 20,90$ & $3,3 \pm 2,90$ & $13,2 / 1,0$ \\
ГПЛ-1 & $1-4$ м, восток & $16.07-26.07$ & $175 \pm 92,0$ & $6,0 \pm 5,60$ & $18,4 \pm 15,00$ & $3,4 / 10,5$ \\
Радуга & $1-4$ м, север & $23.07-01.08$ & $539 \pm 206,0$ & $5,0 \pm 3,20$ & $1,3 \pm 1,50$ & $0,9 / 0,2$ \\
Радуга & 10 м, восток & $23.07-01.08$ & $378 \pm 185,0$ & $0,7 \pm 0,60$ & $0,2 \pm 0,20$ & $0,3 / 0,1$ \\
Радуга & 40 м, запад & $23.07-01.08$ & $506 \pm 213,0$ & $0,4 \pm 0,40$ & 0,0 & $0,1 / 0,0$ \\
Тестер 3 & 20 м, запад & $24.07-01.08$ & $590 \pm 70,0$ & $1,0 \pm 0,80$ & 0,0 & $0,2 / 0,0$
\end{tabular}

П р и м е ч н и е. А - расстояние и направление от доноров пыльцы; Б - срок цветения линий-реципиентов; В - среднее число всех зерен на 1 початок, шт.; Г - число пурпурных зерен от ГП на 1 початок, шт.; Д - число пурпурных зерен от ЗМС-П на 1 початок, шт.; Е - доля пурпурных зерен по донорам ГП/ЗМС-П, \%. ГП - гибрид Пурпурный (донор), ЗМС-П - линия зародышевый маркер Саратовский Пурпурный (донор). Период цветения ГП - с 25 июля по 5 августа, ЗМС-П - с 21 июля по 7 августа. Расположение опытных делянок представлено на рисунке 1.

В наших опытах в условиях Нижнего Поволжья допустимая доля скрещиваний $(0,9 \%)$ наблюдалась для высокорослого реципиента Радуга даже на расстоянии 1-4 м от донора (табл. 1). В исследовании, проведенном в 2000-2003 годах в 15 графствах Англии, также было показано быстрое снижение темпов перекрестного опыления на первых 20 м от донорной культуры $(38,39)$. В экспериментах с кукурузой в условиях Мексики самые высокие значения скрещивания наблюдались вблизи источника пыльцы (12,9 \% на расстоянии 1 м). Степень скрещивания резко снижалась до 4,$6 ; 2,7 ; 1,4 ; 1,0 ; 0,9$ и $0,5 \%$ по мере увеличения расстояния от источника пыльцы соответственно до 2, 4, 8, 12, 16, 20 и 25 м. На расстоянии свыше 20 м частота скрещивания во всех точках составляла 0,9\% ( $\mathrm{p} \leq 0,05)$ и ниже (19).

В условиях засушливого лета 2018 года для гибрида Тестер 3 на расстоянии 20 м на запад от донора ГП процент скрещиваний составлял 0,2 \% 
( $\mathrm{p} \leq 0,05)$, что было значительно ниже порогового значения (см. табл. 1$)$. Интересно отметить, что примерно такая же частота скрещиваний $(0,3 \%)$ $(\mathrm{p} \leq 0,05)$ отмечалась на расстоянии 10 м от ГП у гибрида Радуга, но в направлении на восток, откуда преимущественно дули ветра во время цветения (см. табл. 1).

Эффективность скрещивания зависит от единовременного выхода пыльцы из пыльников донора и появления пестичных нитей у реципиента $(16,40)$. По данным литературы, асинхронность цветения приводила к снижению частоты опыления у реципиента при разнице 4-5 сут на 25 \%, 6 сут на 50 \% (34, 41). Мы тоже наблюдали уменьшение доли переопылений в 4 раза у линии ГПЛ-1 (разница в начале цветения 9 сут с ГП) по сравнению с линией КМ с более близким (разница 1 сут) периодом цветения. При этом частота переопыления у реципиентной линии ГПЛ-1 (раннецветущая) и донора 3МС-П (среднецветущая) увеличивалась в 10 раз по сравнению с КМ (реципиент) и ЗМС-П (донор) (см. табл. 1).

Высота растений доноров пыльцы составляла в среднем для гибрида Пурпурного 2,0-2,5 м, для линии ПС $-1,8$ м, для ЗМС-П $-1,5$ м. В 2018 году число пурпурных зерен после опыления ГП у реципиентных линий было максимальным для форм, находящихся в непосредственной близости, и уменьшалось по мере удаления. Для донора пыльцы ЗМС-П процент скрещиваний с реципиентными линиями сильно падал в направлениях севера и севера-востока, а у реципиентных линий Радуга и Тестер 3, находящихся на западе и юго-западе (см. рис. 1, В), вообе не наблюдалось переопылений от линии ЗМС-П. Возможно, это связано с тем, что высокорослый донор ГП препятствовал распространению пыльцы низкорослого донора линии 3МС-П в этих направлениях. Можно отметить, что у ЗМС-П уже на расстоянии 1-4 м частота скрещиваний с высокорослым реципиентом Радуга была менее $0,9 \%$ ( $\mathrm{p} \leq 0,05)$, а с низкорослой линией КМ ненамного превышала это значение (см. табл. 1).

Один из возможных факторов, ограничивающих поток пыльцы кукурузы, - буферная зона между донором и реципиентом в виде незасеянного или засеянного другим растением участка. В 2019 году мы провели эксперимент по созданию буферной зоны с посевом суданской травы Аллегория, менее рослой, чем донор. Максимальная доля $(1,7-2,1 \%)(\mathrm{p} \leq 0,05)$ пурпурных зерен у реципиента (гибрида Радуга), опыленного донором ПС, наблюдалась в направлениях на запад (блоки 7А-12А) и восток (блоки 7Е12Е) при ширине буферной зоны 3 м от донора пыльцы (см. рис. 1, Г, табл. 2). Для юго-западного направления при ширине буферной зоны 15 м процент скрешиваний $(0,9 \%)(p \leq 0,05)$ не превышал допустимый порог (блоки 13А-13Е, см. рис. 1, Г).

Максимальная частота скрещиваний соответствовала преимущественному направлению ветра (см. рис. 1, Г). При ширине буферной зоны 3 м мы наблюдали достоверное превышение допустимого порога 0,9\% $(\mathrm{p} \leq 0,05)$ для фиолетово окрашенных зерновок в урожае, собранном на делянках 7A-10A и 7Е-10Е, которые отстояли на 0-3 м от буферной зоны (см. табл. 2). На более дальних от донора расстояниях (6-16 м) доля скрещиваний была в пределах 0,3-0,7 \% (p $\leq 0,05)$ в обоих направлениях. При ширине буферной зоны 15 м на расстоянии 15-20 м в юго-западном направлении от донора в початках у гибрида Радуга присутствовало 0,9 \% $(\mathrm{p} \leq 0,05)$ пурпурных зерен, что даже с учетом совпадающего направления ветра не превышало допустимого порога (см. табл. 2). 
2. Частота встречаемости пурпурных зерен в потомстве желтозерного гибрида кукурузы (Zea mays L.) Радуга при свободном опылении донором линии Пурпурная Саратовская ( $A M \pm \mathrm{SD}$, опытное поле РосНИИСК «Россорго», п. Зональный, Саратовский р-н, Саратовская обл., 2019 год)

\begin{tabular}{|c|c|c|c|c|}
\hline $\begin{array}{l}\text { № ряда, } \\
\text { делянки }\end{array}$ & $\begin{array}{l}\text { Направление и расстоя- } \\
\text { ние от донора пыльцы, м }\end{array}$ & $\begin{array}{l}\text { Число почат- } \\
\text { ков, шт. }\end{array}$ & $\begin{array}{l}\text { Среднее число желтых и пур- } \\
\text { пурных зерен на початок, шт. }\end{array}$ & $\begin{array}{l}\text { Доля пурпур- } \\
\text { ных зерен, \% }\end{array}$ \\
\hline $1 \mathrm{~A}-1 \mathrm{E}$ & 30-35 м, северо-восток & 14 & $288,0 \pm 82,31 / 0,00$ & 0,0 \\
\hline $2 \mathrm{~A}-2 \mathrm{E}$ & 25-30 м, северо-восток & 17 & $159,0 \pm 37,04 / 0,5 \pm 1,36$ & 0,3 \\
\hline $3 \mathrm{~A}-3 \mathrm{E}$ & $20-25$ м, северо-восток & 42 & $226,0 \pm 85,60 / 0,2 \pm 0,42$ & 0,1 \\
\hline $4 \mathrm{~A}-4 \mathrm{E}$ & 15-20 м, северо-восток & 49 & $234,0 \pm 84,35 / 0,1 \pm 0,11$ & 0,1 \\
\hline $5 \mathrm{~A}, 12 \mathrm{~A}$ & 10-16 м, запад & 26 & $419,0 \pm 29,63 / 1,2 \pm 0,62$ & 0,3 \\
\hline $6 \mathrm{~A}, 11 \mathrm{~A}$ & 6-12 м, запад & 16 & $368,0 \pm 70,00 / 1,5 \pm 0,12$ & 0,4 \\
\hline $7 \mathrm{~A}-10 \mathrm{~A}$ & 3-6 м, запад & 41 & $520,0 \pm 84,21 / 10,5 \pm 9,32$ & 2,1 \\
\hline $7 \mathrm{E}-10 \mathrm{E}$ & 3-6 м, восток & 37 & $303,0 \pm 40,53 / 4,8 \pm 4,85$ & 1,7 \\
\hline $6 \mathrm{E}, 11 \mathrm{E}$ & 6-12 м, восток & 28 & $303,0 \pm 7,02 / 0,9 \pm 1,13$ & 0,3 \\
\hline $5 \mathrm{E}, 12 \mathrm{E}$ & 10-16 М, востоК & 18 & $302,0 \pm 68,54 / 2,0 \pm 1,91$ & 0,7 \\
\hline $13 \mathrm{~A}-13 \mathrm{E}$ & $15-20$ м, юго-запад & 59 & $406,0 \pm 53,73 / 3,4 \pm 0,81$ & 0,9 \\
\hline $14 \mathrm{~A}-14 \mathrm{E}$ & $20-25$ м, юго-запад & 63 & $360,0 \pm 79,54 / 1,1 \pm 0,52$ & 0,3 \\
\hline $15 \mathrm{~A}-15 \mathrm{E}$ & 25-30 м, юго-запад & 89 & $443,0 \pm 6,31 / 0,7 \pm 0,50$ & 0,2 \\
\hline
\end{tabular}

Пр и м е ч а и е. Период цветения донора и реципиента пыльцы 20-31 июля. Расположение опытных делянок представлено на рисунке 1 .

Следует отметить, что гибрид Радуга в экспериментах 2018-2019 годов демонстрировал относительно низкую частоту скрещиваний (см. табл. 1, 2). Реципиентная кукуруза, особенно высокорослая, сама по себе служит барьером для распространения донорной пыльцы. Возможно, из-за этого при сплошной посадке в 2018 году распространение пыльцы ГП находилось в пределах нормы уже на расстоянии 10 м от донора, а при наличии буферной зоны, засеянной низкорослым растением, в 2019 году порог в 0,9 \% был зарегистрирован на расстоянии 15 м. В работах других авторов также указывается, что буферные зоны с растениями разрыва, в отличие от барьеров с высокорослыми растениями, не приводят к снижению безопасных расстояний (23). Учитывая полученные нами данные, в условиях юго-востока России для исключения рисков переопыления кукурузы можно рекомендовать минимально изолирующее расстояние от 15 м при наличии буферных (незасеянных) зон.

Таким образом, в условиях юго-востока России для исключения переопыления кукурузы выше 0,9 \% может быть рекомендовано изолирующее расстояние 15 м и более. В двух независимых экспериментах (2018 и 2019 годы) мы установили, что на расстоянии соответственно 10 и 15 м от донора пыльцы частота скрещиваний оставалась в пределах допустимой нормы независимо от линии реципиента, сроков цветения и направления ветра. При этом синхронность цветения доноров и реципиентов пыльцы оказывала значительное влияние на частоту скрещиваний. В частности, в условиях 2018 года у реципиентной линии ГПЛ-1 (разница в начале цветения 9 сут с донором гибрид Пурпурный) частота переопылений была в 4 раза меньше по сравнению с линией Коричневый маркер с более близким к донору периодом цветения. Установлено, что более высокорослый донор пыльцы гибрид Пурпурный имеет преимущество при распространении пылыцы по сравнению с низкорослым донором Зародышевый маркер Саратовский - Пурпурный.

Авторы признательны Ю.В. Смолькиной за предоставленные семена гибрида Пурпурного и линии Саратовская Пурпурная, а также И.Б. Ивановой и А.В. Ульянову за помощь в обработке урожая 2019 года.

\section{ЛИТЕРАТУРА}

1. United States Department of Agriculture. World Agricultural Production. Current Report. Circular Series WAP 9-20. October 2020. Режим доступа: https://apps.fas.usda.gov/psdonline/circulars/production.pdf. Дата обращения: 01.07.2020.

2. Zhao C., Liu B., Piao S., Wang X., Lobell D.B., Huang Y., Huang M., Yao Y., Bassu S., Ciais P., 
Durand J.L., Elliott J., Ewert F., Janssens I.A., Li T., Lin E., Liu Q., Martre P., Müller C., Peng S., Pecuelas J., Ruane A.C., Wallach D., Wang T., Wu D., Liu Z., Zhu Y., Zhu Z., Asseng S. Temperature increase reduces global yields of major crops in four independent estimates. Proceedings of the National Academy of Sciences, 2017, 114(35): 9326-9331 (doi: 10.1073/pnas.1701762114).

3. Pellegrino E., Bedini S., Nuti M., Ercoli L. Impact of genetically engineered maize on agronomic, environmental and toxicological traits: a meta-analysis of 21 years of field data. Scientific Reports, 2018, 8(1): 3113 (doi: 10.1038/s41598-018-21284-2).

4. ISAAA. Global Status of Commercialized Biotech/GM Crops: 2016. ISAAA Brief No. 52. ISAAA, Ithaca, NY, 2016.

5. Голиков А.Г., Степанова Н.Г., Красовский О.А., Скрябин К.Г. Конвенция о биологическом разнообразии - развитие взгляда на биобезопасность и биотехнологию. Биотехнология, 1997, 1: 53-58.

6. Чесноков Ю.В. ГМО и генетические ресурсы растений: экологическая и агротехническая безопасность. Вавиловский журнал генетики и селекции, 2011, 15(4): 818-827.

7. Ujj O. European and American views on genetically modified foods. The New Atlantis, 2016, 49: 77-92.

8. McHughen A. A critical assessment of regulatory triggers for products of biotechnology: Product vs. process. GM Crops \& Food, 2016, 7(3-4): 125-158 (doi: 10.1080/21645698.2016.1228516).

9. Ramessar K., Capell T., Twyman R.M., Quemada H., Christou P. Trace and traceability - a call for regulatory harmony. Natural Biotechnology, 2008, 26(9): 975-978 (doi: 10.1038/nbt0908-975).

10. Baram M. Governance of GM crop and food safety in the United States. In: Governing risk in GM agriculture /M. Baram, M. Bourrier (eds.). Cambridge University Press, 2011: 15-56 (doi: 10.1017/CBO9780511976582.003).

11. Чумаков М.И., Гусев Ю.С., Богатырева Н.В., Соколов А.Ю. Оценка рисков распространения генетически модифицированной кукурузы с пыльцой при выращивании с нетрансформированными сортами (обзор). Сельскохозяйственная биология, 2019, 54(3): 426-445 (doi: 10.15389/agrobiology.2019.3.426rus).

12. Marceau A., Gustafson D.I., Brants I.O., Leprince F., Foueillassar X., Riesgo L., Areale F.-J., Sowaf S., Kraicg J., Badeah E.M. Updated empirical model of genetically modified maize grain production practices to achieve European Union labeling thresholds. Crop Science, 2013, 53(4): 1712-1721 (doi: 10.2135/cropsci2012.04.0224).

13. Nicolia A., Manzo A., Veronesi F., Rosellini D. An overview of the last 10 years of genetically engineered crop safety research. Critical Review Biotechnology, 2014, 34(1): 77-88 (doi: 10.3109/07388551.2013.823595).

14. Sirsi E. Coexistence: a new perspective, a new field. Agriculture and Agricultural Science Procedia, 2016, 8: 449-454 (doi: 10.1016/j.aaspro.2016.02.042).

15. Meillet A., Angevin F., Bensadoun A., Huby G., Monod H., Messéan A. Design of a decision support tool for managing coexistence between genetically modified and conventional maize at farm and regional levels. Ecological Informatics, 2015, 30: 379-388 (doi: 10.1016/j.ecoinf.2015.09.014).

16. Devos Y., Reheul D., De Schrijver A. The co-existence between transgenic and non-transgenic maize in the European Union: a focus on pollen flow and cross-fertilization. Environmental Biosafety Research, 2005, 4(2): 71-87 (doi: 10.1051/ebr:2005013).

17. Riesgo L., Areal F.J., Sanvido O., Rodriguez-Cerezo E. Distances needed to limit cross-fertilization between GM and conventional maize in Europe. Nature Biotechnology, 2010, 28(8): 780-782 (doi: 10.1038/nbt0810-780).

18. Galeano P., Debat C.M., Ruibal F., Fraguas L.F., Galván G.A. Cross-fertilization between genetically modified and non-genetically modified maize crops in Uruguay. Environmental Biosafety Research, 2010, 9(3): 147-154 (doi: 10.1051/ebr/2011100).

19. Baltazar B., Castro Espinoza L., Espinoza Banda A., de la Fuente Martínez J.M., Garzón Tiznado J.A., González García J., Gutiérrez M.A., Guzmán Rodríguez J.L., Heredia Díaz O., Horak M.J., Madueño Martínez J.I., Schapaugh A.W., Stojšin D., Uribe Montes H.R., Zavala García F. Pollen-mediated gene flow in maize: implications for isolation requirements and coexistence in Mexico, the center of origin of maize. PloS ONE, 2015, 10(7): e0131549 (doi: 10.1371/journal.pone.0131549).

20. Bückmann H., Thiele K., Schiemann J. CMS maize: a tool to reduce the distance between GM and non-GM maize. EuroChoices, 2016, 15(1): 31-35 (doi: 10.1111/1746-692X.12116).

21. Venus T.J., Dillen K., Punt M.J., Wesseler J.H. The costs of coexistence measures for genetically modified maize in Germany. Journal of Agricultural Economics, 2017, 68(2): 407-426 (doi: 10.1111/1477-9552.12178).

22. Ricci B., Messéana A., Lelièvrec A., Colénod F.C., Angevin F. Improving the management of coexistence between GM and non-GM maize with a spatially explicit model of cross-pollination. European Journal of Agronomy, 2016, 77: 90-100 (doi: 10.1016/j.eja.2016.04.008).

23. Liu Y., Chen F., Guan X., Li J. High crop barrier reduces gene flow from transgenic to conventional maize in large fields. European Journal of Agronomy, 2015, 71: 135-140 (doi: 10.1016/j.eja.2015.09.005).

24. Duncan B., Leyva-Guerrero E., Werk T, Stojšin D., Baltazar B.M., García-Lara S., ZavalaLópez M., de la Fuente-Martínez J.M., Meng C. Assessment of potential impacts associated with gene flow from transgenic hybrids to Mexican maize landraces. Transgenic Research, 2019, 28(5- 
6): 509-523 (doi: 10.1007/s11248-019-00160-3).

25. Bøhn T., Aheto D.W., Mwangala F.S., Fischer K., Bones I.L., Simoloka C., Mbeule I., Schmidt G., Breckling B. Pollen-mediated gene flow and seed exchange in small-scale Zambian maize farming, implications for biosafety assessment. Scientific Reports, 2016, 6: 34483 (doi: 10.1038/srep34483).

26. Киль В.И. Теоретическое обоснование и практическое использование молекулярно-генетических методов в защите сельскохозяйственных растений от вредителей и оценке трансгенных растений на биобезопасность. Автореф. докт. дис. Краснодар, 2010.

27. Ma B.L., Subedi K.D., Reid L.M. Extent of cross-fertilization in maize by pollen from neighboring transgenic hybrids. Crop Science, 2004, 44(4): 1273-1282 (doi: 10.2135/cropsci2004.1273).

28. Bannert M., Stamp P. Cross-pollination of maize at long distance. European Journal of Agronomy, 2007, 27(1): 44-51 (doi: 10.1016/j.eja.2007.01.002).

29. Langhof M., Hommel B., Hüsken A., Schiemann J., Wehling P., Wilhelm R., Rühl G. Coexistence in maize: do nonmaize buffer zones reduce gene flow between maize fields? Crop Science, 2008, 48(1): 305-316 (doi: 10.2135/cropsci2007.04.0189).

30. Гуторова О.В., Апанасова Н.В., Юдакова О.И. Создание генетически маркированных линий кукурузы с наследуемыми и индуцированными типами партеногенеза. Известия $\mathrm{Ca}$ марского научного центра Российской академии наук, 2016, 18(2): 341-344.

31. Coe E.H. Jr. A line of maize with high haploid frequency. The American Naturalist, 1959, 93(873): 381-382 (doi: 10.1086/282098).

32. Смолькина Ю.В., Сериков Л.В., Калашникова Э.В. Выявление гаплоидов у пурпурных форм кукурузы. Бюллетень ботанического сада Саратовского государственного универсиmema, 2004, 3(1): 144-148.

33. Chamecki M., Gleicher S.C., Dufault N.S., Isard S.A. Diurnal variation in settling velocity of pollen released from maize and consequences for atmospheric dispersion and cross-pollination. Agricultural and Forest Meteorology, 2011, 151(8): 1055-1065 (doi: 10.1016/j.agrformet.2011.03.009).

34. Luna S., Figueroa J., Baltazar B., Gomez R., Townsend R., Schoper J.B. Maize pollen longevity and distance isolation requirements for effective pollen control. Crop Science, 2001, 41(5): 15511557 (doi: 10.2135/cropsci2001.4151551x).

35. Angevin F., Klein E., Choimet C., Meynard J., de Rouw A., Sohbi Y. Modélisation des effets des systèmes de culture et du climat sur les pollinisations croisées chez le maïs. Isolement des collectes et maitrise des disséminations au champ. In: Rapport du groupe 3 du programme de recherche: pertinence économique et faisabilité d'une filiure sans utilisation d'OGM, INRAFNSEA /J.-M. Meynard, M. Le Bail (eds.). Thiverval-Grignon, France, 2001: 21-36.

36. Jarosz N., Loubet B., Durand B., Foueillassar X., Huber L. Variations in maize pollen emission and deposition in relation to microclimate. Environmental Science \& Technology, 2005, 39(12): 4377-4384 (doi: 10.1021/es0494252).

37. Гуторова О.В. Качество пыльцы и особенности строения мужского гаметофита у гаплоиндуцирующих линий кукурузы и их гибридов. Бюллетень Ботанического сада Саратовского государственного университета, 2016, 14(2): 62-70.

38. Henry C., Morgan D., Weekes R., Daniels R., Boffey C. Farm scale evaluations of GM crops: monitoring gene flow from GM crops to non-GM equivalent crops in the vicinity: Part I: Forage maize. DEFRA report EPG, 2003.

39. Weekes R., Allnutt T., Boffey C., Morgan S., Bilton M., Daniels R., Henry C. A study of cropto-crop gene flow using farm scale sites of fodder maize (Zea mays L.) in the UK. Transgenic Research, 2007, 16(2): 203-211 (doi: 10.1007/s11248-006-9036-0).

40. Westgate M., Lizaso J., Batchelor W. Quantitative relationship between pollen-shed density and grain yield in maize. Crop Science, 2003, 43(3): 934-942 (doi: 10.2135/cropsci2003.9340).

41. Della Porta G., Ederle D., Bucchini L., Prandi M., Verderio A., Pozzi C. Maize pollen mediated gene flow in the Po valley (Italy): Source-recipient distance and effect of flowering time. European Journal of Agronomy, 2008, 28(3): 255-265 (doi: 10.1016/j.eja.2007.07.009).

1ФГБУН Институт биохимии и физиологии растений и микроорганизмов РАН,

Поступила в редакцию

410049 Россия, г. Саратов, просп. Энтузиастов, 13,

e-mail: gusev_yu@ibppm.ru, olga.gutorova@mail.ru,

em-moiseeva@mail.ru, vvf2593@gmail.com, volokhina_i@ibppm.ru,

chumakovmi@gmail.com $\square$;

2 ФГБНУ Российский научно-исследовательский

и проектно-технологический институт сорго и кукурузы,

410050 Россия, г. Саратов, 1-й Институтский проезд, 4,

e-mail: zea_mays@mail.ru,genomix@mail.ru,e.a.zhuk@yandex.ru

Sel'skokhozyaistvennaya biologiya [Agricultural Biology], 2021, V. 56, № 1, pp. 66-77

\section{ASSESSMENT OF THE RISKS OF CROSS-POLLINATION}




\title{
DURING CO-CULTIVATION OF MAIZE LINES IN THE SOUTH-EAST EUROPEAN RUSSIA
}

\author{
Yu.S. Gusev', O.V. Gutorova ${ }^{1}$, E.M. Moiseeva ${ }^{1}$, V.V. Fadeev', S.A. Zaytsev², \\ D.P. Volkov', E.A. Zuk², I.V. Volokhina', M.I. Chumakov' ${ }^{\bowtie}$
}

\begin{abstract}
${ }_{1}^{1}$ Institute of Biochemistry and Physiology of Plants and Microorganisms RAS, 13, prosp. Entuziastov, Saratov, 410049 Russia, email gusev_yu@ibppm.ru, olga.gutorova@mail.ru, em-moiseeva@mail.ru, vvf2593@gmail.com, volokhina_i@ibppm.ru, chumakovmi@gmail.com (corresponding author $\square$ );

${ }^{2}$ Russian Research, Design and Technology Institute for Sorghum and Maize, 4, 1-i Institutskii proezd, Saratov, 410050 Russia, e-mail zea_mays@mail.ru,genomix@mail.ru, e.a.zhuk@yandex.ru

ORCID:

Gusev Yu.S. orcid.org/0000-0001-7379-484X

Gutorova O.V. orcid.org/0000-0002-6975-8675

Moiseeva E.M. orcid.org/0000-0001-9234-4000

Fadeev V.V. orcid.org/0000-0002-9725-3439

Zaytsev S.A. orcid.org/0000-0002-6829-1970

Volkov D.P. orcid.org/0000-0001-8055-6516

Zuk E.A. orcid.org/0000-0001-6763-3724

Volokhina I.V. orcid.org/0000-0002-9088-481X

Chumakov M.I. orcid.org/0000-0002-6396-2851

The authors declare no conflict of interests

Acknowledgements:

The authors are grateful to Yu.V. Smolkina for seeds of the hybrid Purpurnii and the line Saratovskaya Purpurnaya, and to I.B. Ivanova and A.V. Ul'yanov for help in handling the 2019 crop.

Supported financially under the Program of Basic Scientific Research of State Academies of Sciences for 2020, the State registration No. AAAA-A17-117102740101-5 (for GM corn obtaining and risk assessment), and with the grant No. 18-29-14048mk from the Russian Foundation for Basic Research (for modeling GM corn behavior in field conditions)

Received July 3, 2020

doi: 10.15389 /agrobiology.2021.1.66eng
\end{abstract}

\section{Abstract}

The new Russian Federal law (No. 358 of 03.07.2016) prohibits the commercial use of GM plants in agriculture, but allows, since 2018, for the first time in Russia their cultivation and testing for research purposes. Consequently, there is a need to assess and develop criteria for safe co-cultivation of non-GM and GM varieties, which are currently absent in Russia. In this paper, it was established for the first time that the $10-15 \mathrm{~m}$ distance is sufficient to prevent cross-pollination between maize lines with an acceptable presence of $0.9 \%$ of the donor's genetic material, regardless of the recipient line, donor and recipient time flowering, and the wind direction in Saratov condition (South-West region of European part of Russia). The work aimed to assess the influence of the distance between pollen donor and recipient, wind direction, donor and recipient time flowering, and a buffer zone presence between them on the crossing frequency in mixed maize crops. The maize lines Korichnevyi marker (KM), GPL-1, Zarodyshevyi marker Saratovskii Purpurnyi (ZMS-P), Purpurnaya Saratovskaya (PS), as well as hybrids Purpurnyi (GP), Raduga and Tester 3 were grown (the experimental field of the Rossorgo, Saratov, South-West region of European Russia, 2018-2019). We planted the GP and ZMS-P lines as pollen donors in 2018 on a $3 \times 80 \mathrm{~m}^{2}$ area with planting density of 7-10 plants per $1 \mathrm{~m}^{2}$. Between the pollen donor area, maize KM and GPL-1 lines were planted, and around them there were a $1290 \mathrm{~m}^{2}$ area of yellow-colored grain recipients (Raduga and Tester 3 hybrids). In September, 5-12 ears from each pollen recipient were harvested. The cross-pollination frequency was calculated as the ratio of purple grains (GP pollination result) or yellow grains with a purple spot (ZMS-P pollination result) to the total grain number in recipient lines. In 2018 it was established that the maximum percentage (from 0.1 to $13.2 \%$ ) derived from cross-pollination with two pollen donors depends on different factors. At closer distances (1-4 m), the cross-pollination increased 4-fold for the earlier flowering recipient. The percentage of crosses for recipient Raduga decreased 3 times with a $10 \mathrm{~m}$ increase in the distance and 11 times at a $40 \mathrm{~m}$ distance from the donor plants. Experiments in 2018 indicate that the $10 \mathrm{~m}$ distance from the pollen donor guarantees the percentage of crosses not exceeding the $0.9 \%$ GM threshold in food products accepted in the European Union and Russia. In 2019, we used PS inbred line as a pollen donor. The PS was planted on a $3 \times 5 \mathrm{~m}$ plot with Sudanese grass (Sorghum $\times$ drummondii) Allegory cultivar as a buffer zone $3 \mathrm{~m}$ wide to the East and West and $15 \mathrm{~m}$ long to the South-West and North-East. Yellow-grain hybrid Raduga was planted around the buffer zone. The frequency of crosses was calculated as the ratio of the number of purple grains to the total number of Raduga grains per ear. In 2018, the frequency of crosses was also estimated depending on the synchronism of flowering between pollen donors and recipients. The GPL-1 recipient with a 9-day difference from PG (pollen donor) in the beginning of flowering showed a $4 \%$ lower pollination rate compared to a KM line with a flowering period closer to the PG pollen donor (1-day difference). Tall plants of PG donor of pollen prevented spreading pollen from a short ZMS-P donor to the Tester 3 and Raduga recipients in the direction of the wind rose. In 2019, no more than $0.9 \%$ of purple grains were observed for the recipient Raduga when using a buffer zone of $15 \mathrm{~m}$ and more from the pollen donor in the wind rose direction. Based on the results of field experiments, the isolation distance from $15 \mathrm{~m}$ or more can be recommended to exclude cross-pollination of maize within the threshold of $0.9 \%$ in the conditions of the South-East of the European part of Russia.

Keywords: GM plants, cross-pollination risks, maize, buffer zones. 